\title{
Meta-analysis on the effect of the N363S polymorphism of the glucocorticoid receptor gene (GRL) on human obesity
} Amelia Marti*†1, M Carmen Ochoa ${ }^{\dagger 1}$, Almudena Sánchez-Villegas ${ }^{2,3}$, J Alfredo Martínez¹, Miguel Angel Martínez-González², Johannes Hebebrand4, Anke Hinney ${ }^{4}$ and Helmut Vedder ${ }^{5}$

\author{
Address: ${ }^{1}$ Department of Physiology and Nutrition, University of Navarra, Pamplona, Spain, ${ }^{2}$ Department of Preventive Medicine and Public \\ Health, University of Navarra, Pamplona, Spain, ${ }^{3}$ Department of Clinical Sciences, University of Las Palmas de Gran Canaria, Spain, ${ }^{4}$ Department \\ of Child and Adolescent Psychiatry, Rheinische Kliniken Essen, Essen, Germany and ${ }^{5}$ Department of Psychiatry and Psychotherapy, Philipps- \\ University of Marburg, Marburg, Germany \\ Email: Amelia Marti* - amarti@unav.es; M Carmen Ochoa - MOCHNIE@ALUMNI.UNAV.ES; Almudena Sánchez- \\ Villegas - asanchez@dcc.ulpgc.es; J Alfredo Martínez - jalfmtz@unav.es; Miguel Angel Martínez-González - mamartinez@unav.es; \\ Johannes Hebebrand - Johannes.Hebebrand@uni-duisburg-essen.de; Anke Hinney - anke.hinney@uni-duisburg-essen.de; \\ Helmut Vedder - vedder@med.uni-marburg.de \\ * Corresponding author †Equal contributors
}

Published: 25 May 2006

BMC Medical Genetics 2006, 7:50 doi:10.1 186/147I-2350-7-50
Received: 14 October 2005

Accepted: 25 May 2006

This article is available from: http://www.biomedcentral.com/I47/-2350/7/50

(c) 2006 Marti et al; licensee BioMed Central Ltd.

This is an Open Access article distributed under the terms of the Creative Commons Attribution License (http://creativecommons.org/licenses/by/2.0), which permits unrestricted use, distribution, and reproduction in any medium, provided the original work is properly cited.

\begin{abstract}
Background: Since both excess glucocorticoid secretion and central obesity are clinical features of some obese patients, it is worthwhile to study a possible association of glucocorticoid receptor gene (GRL) variants with obesity. Previous studies have linked the N363S variant of the GRL gene to increased glucocorticoid effects such as higher body fat, a lower lean-body mass and a larger insulin response to dexamethasone. However, contradictory findings have been also reported about the association between this variant and obesity phenotypes. Individual studies may lack statistical power which may result in disparate results. This limitation can be overcome using meta-analytic techniques.
\end{abstract}

Methods: We conducted a meta-analysis to assess the association between the N363S polymorphism of the GRL gene and obesity risk. In addition to published research, we included also our own unpublished data -three novel case-control studies- in the meta-analysis The new case-control studies were conducted in German and Spanish children, adolescents and adults (total number of subjects: I,I I7). Genotype was assessed by PCR-RFLP (Tsp5091). The final formal metaanalysis included a total number of 5,909 individuals.

Results: The meta-analysis revealed a higher body mass index (BMI) with an overall estimation of $+0.18 \mathrm{~kg} / \mathrm{m}^{2}(95 \% \mathrm{Cl}$ : +0.004 to +0.35 ) for homo-/heterozygous carriers of the $363 \mathrm{~S}$ allele of the GRL gene in comparison to non-carriers. Moreover, differences in pooled BMI were statistically significant and positive when considering one-group studies from the literature in which participants had a BMI below $27 \mathrm{~kg} / \mathrm{m}^{2}\left(+0.4 \mathrm{l} \mathrm{kg} / \mathrm{m}^{2}[95 \% \mathrm{Cl}+0.17\right.$ to +0.66$\left.]\right)$, but the differences in BMI were negative when only our novel data from younger (aged under 45 ) and normal weight subjects were pooled together $\left(-0.50 \mathrm{~kg} / \mathrm{m}^{2}[95 \% \mathrm{Cl}-0.84\right.$ to -0.17$\left.]\right)$. The overall risk for obesity for homo-/heterozygous carriers of the $363 \mathrm{~S}$ allele was not statistically significant in the meta-analysis (pooled $\mathrm{OR}=1.02 ; 95 \% \mathrm{Cl}$ : $0.56-1.87$ ).

Conclusion: Although certain genotypic effects could be population-specific, we conclude that there is no compelling evidence that the N363S polymorphism of the GRL gene is associated with either average BMI or obesity risk. 


\section{Background}

Since 1990, important efforts have been made to identify genes influencing complex traits, often by relying on the use of a priori selected candidate genes. According to the updated 2004 version of the Human Obesity Map, 113 candidate genes showed initial association with obesity, out of which only 18 genes are supported by at least five positive studies [1-3]. Since both excess glucocorticoid secretion and central obesity are clinical features of some obese patients, it is worthwhile to study a possible association of glucocorticoid receptor gene (GRL) variants with obesity $[4,5]$. The GRL gene is located on chromosome $5 \mathrm{q} 31.3$ and is also named nuclear receptor subfamily 3, group $\mathrm{C}$, member 1 (NR3C1). There are three known polymorphisms in the GRL gene -BclI, ER22/23EK, N363Swith the last two involved an aminoacid sequence change [6-17]. The N363S variant of the GRL gene increases the trans-activating capacity both in vivo e in vitro, and it has been shown to be associated with an increased sensitivity to glucocorticoids in vivo. An association of the variant N363S with measures of increased glucocorticoid effects such as more body fat, a larger insulin response to dexamethasone and a less lean-body mass has been reported $[5,7]$.

The polymorphism N363S (rs6195) in exon 2 of the GRL (U78506) is present with allele frequencies ranging from $0.7 \%$ in a South Asian population [13] to $27 \%$ in Australian subjects [12]. This polymorphism was reported to be associated with an increased body mass index (BMI), an increased weight gain or a higher waist to hip ratio in some populations, i. e. in Dutch, Anglo-Celtic, French and Australian individuals $[6,7,11,15,16]$, while other studies performed on Danish, Swedish, and South Asian subjects were not able to confirm this finding [9,10,12-14,17]. The disparity of the results may partly be attributed to insufficient power in some of these studies, false positive or negative findings, or other reasons such as methodological issues, or the heterogeneity in age, sex, ethnic origin or average BMI of participants.

To further explore the role of the N363S polymorphism of the GRL gene in human obesity, we examined novel casecontrol data from two Spanish and one German study and included the results in a meta-analysis of a large number of previously published studies.

To overcome the limitations of the previous research work, we pooled data from different studies including our own results to rigorously assess any association and ascertain the likelihood and magnitude of the association between the allelic variants and the phenotype of interest [18-21]. Because non-significant results can be due to type 2 errors, meta-analyses greatly increase the power [20] and thus reduce the probability of false negative findings. On the other hand, some of the apparently significant results are simply due to type 1 errors resulting from spurious findings. Consequently, data pooling also reduces the type 1 error rate.

Therefore, we performed a meta-analysis by combining our data from three novel case-control studies $(n=1,117)$ with a number of previously reported studies $(n=4,792)$, to gain convincing evidence for (or against) the association between the N363S polymorphism of the GRL gene and obesity risk. A family-based study was also conducted in 124 German obesity trios (obese child or adolescent and both of their biological parents).

\section{Methods \\ Study population}

The study population was recruited from Spain (Navarra) and Germany. Two Spanish studies following a case-control design were conducted as described in detail elsewhere [22,23], see Table 1 for phenotypic details. The first case-control study comprised 370 children and adolescents (185 obese and 185 control subjects). Obesity was defined according to a body mass index (BMI) above the 97 th percentile for sex and age according to Spanish reference data [22]. Controls had a BMI below the 90th percentile. The participants were mostly Caucasians (98.4\%) originating from an homogeneous population of a limited geographical area in Northern Spain (Navarra) except for a small proportion of subjects $(1.6 \%)$ that were nonCaucasian (3 subjects from South American, 1 Hindu, 1 Afro-American and 1 Gypsy subject). The second (adult) case-control study included 159 obese subjects with a BMI $\geq 30 \mathrm{~kg} / \mathrm{m}^{2}$ and 154 lean controls with BMIs below $25 \mathrm{~kg} /$

Table I: Phenotypic characteristics of the two Spanish case-control studies

\begin{tabular}{lcccc}
\hline & \multicolumn{2}{c}{ Navarra children } & Navarra adults \\
\hline & Obese $(\mathbf{n}=\mathbf{1 8 5})$ & Controls $(\mathbf{n}=\mathbf{1 8 5})$ & Obese $(\mathbf{n}=\mathbf{1 5 9})$ & Controls $(\mathbf{n}=\mathbf{1 5 4})$ \\
\hline \% Male & $53 \%$ & $53 \%$ & $12.6 \%$ & $26.6 \%$ \\
Age (years) & $11.4(11.0-11.8)$ & $11.7(11.3-12.1)$ & $42(41-44)$ & $39(37-40)$ \\
BMI (kg/m $\left.{ }^{2}\right)$ & $27.6(26.9-28.3)$ & $19.0(18.6-19.4)$ & $37.6(36.7-38.5)$ & $22.3(22.0-22.6)$ \\
Percentage body fat & $34.3(34.1-36.4)$ & $18.2(16.8-19.5)$ & $43.4(42.3-44.6)$ & $27.5(26.7-28.3)$ \\
\hline
\end{tabular}

Data are presented as mean $(95 \% \mathrm{Cl})$. 
$\mathrm{m}^{2}$ [23]. All participants were Caucasians originating from a homogeneous population of a limited geographical area in Northern Spain (Navarra). The German study included 178 extremely obese children and adolescents - BMI above the 99th percentile for age and sex compared to a representative German population sample [24] - and 256 lean young adults (BMI $\leq 15$ th percentile) serving as controls. The mean BMI (SD) was $35.6(6.1) \mathrm{kg} / \mathrm{m}^{2}$ for the obese group and $\left.18.2(1.11) \mathrm{kg} / \mathrm{m}^{2}\right)$ for the control group. $50 \%$ of the obese subjects and $49 \%$ of the controls were male.

The German study of case-parents encompassed 124 extremely obese children and adolescents (BMI $\geq 99$ th BMI percentile according to German reference data [24] and both of their parents. It is worth mentioning that obese children and adolescents included in the case-parent study were independent of the individuals included in the case-control study. All participants of the German study groups were Caucasians recruited in West and South Germany.

The study was approved by the Ethics Committee of each University, and all subjects, (and, in case of minors, their parents) provided written informed consent. The reported investigation was carried out according to the principles of the Declaration of Helsinki II.

\section{Procedures}

Extraction of genomic DNA was performed according to standard protocols. The N363S polymorphism of the GRL gene was analyzed by PCR-RFLP (digestion with Tsp509I) as described previously [11]. For validity of the genotypes, allele determination was made independently by at least two experienced individuals. Discrepancies were solved unambiguously either by reaching consensus or by repeating the experimental procedure. In addition, we checked for Mendelian inconsistencies in the trios with the program Pedcheck [25].

\section{Statistical analysis}

Descriptive values are given as mean and standard error of the mean. Univariate statistical analysis was performed using unpaired Student t-test and Chi square test (for frequencies).

The Transmission-Disequilibrium Test (TDT) was used to assess the differential pattern of excess transmission of alleles from heterozygous parents to diseased children [26]. By sampling family trios including the affected children and adolescents (probands), the association between N363S allele and obesity would lead to a transmission type different from the expected probability of 0.5 . When cases are unrelated probands, TDT represents a valid test of association, even if a population stratification is present [26].

\section{Meta-analysis}

To systematically review differences in BMI across the presence/absence of the N363S polymorphism of the GRL gene (including homozygous and heterozygous subjects for the 363 S allele together) we used a formal meta-analysis [27]. Procedures of formal meta-analysis have been mostly applied to combine the results from previously reported studies[28]. However, in the current meta-analysis, we also included data from three of our own studies that have not been published yet.

A Pubmed search revealed 16 studies published before April 2005 focusing on the analysis of the N363S polymorphism of the GRL gene in human (obese or lean) subjects. Subsequently, these were included in the present analysis. Since new information was required on the frequencies of the N363S polymorphism of the GRL gene according to different BMI categories, we personally contacted all authors to obtain additional information by personal communication ( 12 of the 16 studies). Therefore, we were able to combine data from 12 studies with a total of 4,792 subjects from the literature and data from our present investigation on 1,117 subjects. Thus, the total number of subjects in the meta-analysis was 5,909 subjects.

The meta-analysis provides a logical structure for systematically quantifying evidence and for exploring bias and diversity in research[27]. In our meta-analysis, the presence/absence of the polymorphism was considered as the exposure, whereas a change in BMI was considered as the outcome. The average difference in BMI between individuals with or without the N363S polymorphism (homo-/ heterozygous carriers of the $363 \mathrm{~S}$ allele vs. non-carriers) of the GRL gene was used as the outcome.

We estimated a summary difference $\left(\mathrm{d}_{\mathrm{s}}\right)$ as the weighted effect size [29]:

$d_{s}=d_{i} w_{i} w_{i}$

$d_{s}$ is the pooled estimate across studies for the difference in the BMI $\left(\mathrm{kg} / \mathrm{m}^{2}\right)$ in homo-/heterozygous carriers and non-carriers of 363 Ser allele, $\mathrm{w}_{\mathrm{i}}$ is the weight assigned to each study $\left(w_{i}\right.$ is the inverse of the variance for the difference in BMI found in each study) and $\mathrm{d}_{\mathrm{i}}$ is the BMI difference between those with or without the N363S polymorphism in each individual study. We also calculated a $95 \%$ confidence interval (CI) for the pooled difference in BMI:

$95 \% \mathrm{CI}=\mathrm{d}_{\mathrm{s}} \pm(1.96 \times \mathrm{SE})$

where SE is the standard error of the pooled estimate [27]. 
Table 2: Mean and difference $(95 \% \mathrm{Cl})$ in body mass index $\left(\mathrm{kg} / \mathrm{m}^{2}\right)$ between individuals homozygous and heterozygous carriers of the 3635 allele of the GRL gene and homozygotes for the N363 allele in studies with two population group

\begin{tabular}{|c|c|c|c|c|c|c|c|c|c|c|c|c|c|c|c|c|}
\hline \multirow{3}{*}{ Study } & \multicolumn{8}{|c|}{ Normal weight subjects } & \multicolumn{8}{|c|}{ Obese subjects } \\
\hline & \multicolumn{2}{|c|}{$\begin{array}{l}N 363 / 363 S \\
363 S / 363 S\end{array}$} & \multicolumn{2}{|c|}{ N363/N363 } & \multirow[t]{2}{*}{$\begin{array}{c}\text { Mean } \\
\text { difference }\end{array}$} & \multicolumn{2}{|c|}{$95 \% \mathrm{Cl}$} & \multirow[t]{2}{*}{$\begin{array}{c}\% \\
\text { carriers }\end{array}$} & \multicolumn{2}{|c|}{$\begin{array}{l}N 363 / 363 S \\
363 S / 363 S\end{array}$} & \multicolumn{2}{|c|}{ N363/N363 } & \multirow[t]{2}{*}{$\begin{array}{c}\text { Mean } \\
\text { difference }\end{array}$} & \multicolumn{2}{|c|}{$95 \% \mathrm{Cl}$} & \multirow[t]{2}{*}{$\begin{array}{c}\% \\
\text { carriers }\end{array}$} \\
\hline & $\mathrm{n}$ & $\begin{array}{l}\text { Mean } \\
\text { BMI }\end{array}$ & $\mathrm{n}$ & $\begin{array}{l}\text { Mean } \\
\text { BMI }\end{array}$ & & & & & $n$ & $\begin{array}{c}\text { Mean } \\
\text { BMI }\end{array}$ & $\mathrm{n}$ & $\begin{array}{l}\text { Mean } \\
\text { BMI }\end{array}$ & & & & \\
\hline \multicolumn{17}{|l|}{$\begin{array}{c}\text { Published } \\
\text { data }\end{array}$} \\
\hline $\begin{array}{c}\text { Lin et al. } \\
1999\end{array}$ & 27 & 26.5 & 171 & 25.7 & 0.8 & -0.9 & 2.5 & 13.64 & 39 & 43.6 & 107 & 42.9 & 0.7 & -2.5 & 3.8 & 26.71 \\
\hline $\begin{array}{l}\text { Lin et al. } \\
2003\end{array}$ & 33 & 26.6 & 230 & 25.6 & 1.0 & -0.5 & 2.5 & 12.55 & 39 & 43.5 & 111 & 43.1 & 0.4 & -2.7 & 3.5 & 26.00 \\
\hline $\begin{array}{l}\text { Echwald et } \\
\text { al. 200I }\end{array}$ & 79 & 26.4 & 775 & 26.1 & 0.2 & -0.6 & 1.1 & 9.25 & 66 & 35.9 & 675 & 35.7 & 0.2 & -1.2 & 1.7 & 8.91 \\
\hline Total (n) & 139 & & 1176 & & & & & & 144 & & 893 & & & & & \\
\hline \multicolumn{17}{|l|}{$\begin{array}{c}\text { Spain } \\
\text { (Navarra) }\end{array}$} \\
\hline Adults & 7 & 22.4 & 147 & 22.3 & 0.1 & -1.3 & 1.4 & 4.54 & 2 & 37.1 & 157 & 37.6 & -0.5 & -8.5 & 7.5 & 1.26 \\
\hline $\begin{array}{l}\text { Children } \\
\text { Germany }\end{array}$ & 8 & 18.6 & 177 & 18.9 & -0.3 & -2.2 & 1.6 & 4.32 & 4 & 24.3 & 181 & 27.6 & -3.3 & -7.9 & 1.3 & 2.16 \\
\hline $\begin{array}{l}\text { Children and } \\
\text { adolescents }\end{array}$ & 22 & 17.6 & 234 & 18.3 & -0.7 & -1.2 & -0.2 & 8.59 & 8 & 41.3 & 170 & 35.4 & 5.9 & 1.7 & 10.2 & 4.49 \\
\hline Total (n) & 37 & & 558 & & & & & & 14 & & 508 & & & & & \\
\hline
\end{tabular}

In the study by Echwald et al (200I) only men were recruited from Copenhagen, Denmark, mean age $=45$. The study by Lin et al $(1999)$ included men $(53 \%)$ and women $(47 \%)$, mean age $=50$, from Sydney (Australia), the study by Lin et al $(2003)$ included men $(80 \%)$ and women $(20 \%)$, mean age $=45$, from Sydney (Australia). The Navarra adults study enrolled men $(20 \%)$ and women $(80 \%)$, mean age $=40$, from Navarra (North of Spain). The Navarra children study encompassed boys $(53 \%)$ and girls $(53 \%)$, mean age $=$ I I from Navarra (North of Spain). The German children study consisted of boys $(50 \%)$ and girls $(50 \%)$, mean age $=14$ from West and South of Germany.

A test of heterogeneity was also calculated, estimating a $\mathrm{Q}$ statistic, which follows a Chi-square distribution with degrees of freedom of $\mathrm{k}-1, k$ being the number of studies included in the analysis. A two-tailed $p$ value $<0.05$ for this statistic parameter indicates the presence of heterogeneity, which somewhat compromises the validity of the pooled estimates [30]. For the pooled odds ratio we used the DerSimonian and Laird's random effect model [31].

Because significant heterogeneity was clearly evident in the pooled difference estimates for all studies combined, we evaluated potential sources of heterogeneity by subset analysis [27]. We analysed sub-groups using the following criteria: firstly, unpublished studies which included six datasets from the present investigation considering obese and control subjects and children and adolescents $v s$. adult subjects; secondly, published studies with one population group (nine studies); thirdly, published studies with two groups - an obese and a lean subject group (three studies, six datasets). We also repeated the meta- analysis in subgroups built according to the prevalence of the mutation -homo-/heterozygous carriers- $(<5 \%$; $5-$ $10 \%$ : $>10 \%$ ), according to ethnicity, and according to the gender of participants.

\section{Results}

Studies on Spanish and German populations

In this work, firstly we examined the N363S polymorphism of the GRL gene in two Spanish case-control studies. The main phenotypic characteristics of the Spanish adults and children study groups are given in Table 1 . The German population was composed of 178 extremely obese children and adolescents (mean age 14, 50\% boys) and 256 lean young adults (mean age 25, 50\% male) as indicated in the Methods section.

The percentages of homo-/heterozygous carriers of the 363 allele of the GRL gene for each study group are shown in Table 2. Values ranged from $1.26 \%$ in the Spanish adult obese subjects to $8.59 \%$ in the German control 
Table 3: Mean and difference $(95 \% \mathrm{Cl})$ in body mass index $\left(\mathrm{kg} / \mathrm{m}^{2}\right)$ between individuals homozygous and heterozygous carriers of the 3635 allele of the GRL gene and homozygotes for the N363 allele in studies with one population group

\begin{tabular}{|c|c|c|c|c|c|c|c|c|c|c|c|}
\hline \multirow[t]{2}{*}{ Study } & \multicolumn{2}{|c|}{$\begin{array}{c}363 S / N 363363 S / \\
363 S\end{array}$} & \multicolumn{2}{|c|}{ N363/N363 } & \multicolumn{3}{|c|}{ Mean difference } & \multirow[t]{2}{*}{$\begin{array}{c}\% \\
\text { carriers }\end{array}$} & \multirow[t]{2}{*}{ City, origin } & \multirow[t]{2}{*}{$\begin{array}{l}\text { Age, } \\
\text { gender }\end{array}$} & \multirow[t]{2}{*}{ Ref } \\
\hline & $\mathbf{n}$ & $\begin{array}{l}\text { Mean } \\
\text { BMI }\end{array}$ & $\mathbf{n}$ & $\begin{array}{c}\text { Mean } \\
\text { BMI }\end{array}$ & & $95 \% \mathrm{Cl}$ & & & & & \\
\hline Huizenga 98 & 12 & 28.1 & 198 & 26.6 & 1.5 & 1.3 & 1.7 & 5.7 & $\begin{array}{l}\text { Rotterdam, } \\
\text { Netherlands }\end{array}$ & $\begin{array}{l}\text { 66-68, } \\
\text { both }\end{array}$ & 6 \\
\hline Halsall 00 & 38 & 26.3 & 453 & 25.8 & 0.5 & 0.4 & 0.6 & 7.7 & $\begin{array}{l}\text { Isle of Ely, } \\
\text { UK }\end{array}$ & $54, \mathrm{NA}$ & 7 \\
\hline Rosmond $0 \mathrm{I}$ & 25 & 26.0 & 243 & 26.2 & -0.2 & -1.8 & 1.4 & 9.3 & $\begin{array}{l}\text { Gotenburg, } \\
\text { Sweden }\end{array}$ & NA, men & 8 \\
\hline Dobson 01 & 23 & 26.1 & 352 & 26.6 & -0.5 & -2.6 & 1.7 & 6.1 & $\begin{array}{l}\text { Newcastle, } \\
\text { UK }\end{array}$ & 54 , both & 9 \\
\hline Morris 03 & 46 & 41.7 & 122 & 45.0 & -3.3 & -6.3 & -0.3 & 27.4 & $\begin{array}{l}\text { Sydney, } \\
\text { Australia }\end{array}$ & NA, NA & 11 \\
\hline Rosmond 03 & 15 & 27.5 & $|4|$ & 27.1 & 0.4 & -1.6 & 2.4 & 9.6 & $\begin{array}{l}\text { Sävedalen, } \\
\text { Sweden }\end{array}$ & NA, men & 10 \\
\hline Roussel 03 & 20 & 29.6 & 349 & 28.0 & 1.6 & -0.5 & 3.7 & 5.4 & Paris, France & 62 , both & 12 \\
\hline Wüst 04 & 16 & 21.1 & 92 & 22.0 & -0.8 & -2.4 & 0.7 & 14.8 & $\begin{array}{l}\text { Trier, } \\
\text { Germany }\end{array}$ & I8, men & 14 \\
\hline Syed 04 & 2 & 28.2 & 293 & 27.1 & 1.1 & -5.3 & 7.4 & 0.7 & $\begin{array}{l}\text { South Asian, } \\
\text { UK }\end{array}$ & 5I, both & 13 \\
\hline Total (n) & 197 & & 2243 & & & & & & & & \\
\hline
\end{tabular}

NA: not available

group and were higher in the German than in the Spanish participants and in controls versus obese subjects. All Spanish carriers were heterozygous for the polymorphism N363S of the GRL gene. Only one homozygous carrier for the 363 S allele was found among the German extremely obese children and adolescents. All study groups fulfilled Hardy-Weinberg equilibrium.

Apart from these three study groups, a family-based association study was also conducted separately in 124 German trios. 15 parents were heterozygous for the N363S polymorphism of the GRL gene, of which 8 transmitted the allele 363S ( $p$-value $=0.99)$. Hence, we detected no transmission disequilibrium for the N363S polymorphism of the GRL gene in the population studied.

\section{Published studies included in the meta-analysis}

The number and mean BMI for homo-/heterozygous carriers the 363S allele of each study are described in Table 2 (studies with one obese and one normal weight subject group) and Table 3 (only one group). We combined data from 12 studies from the literature having either one or two groups of subjects (cases and controls) with a total of 4,792 subjects. As seen in Table 4, we performed several types of analysis. We pooled published studies with only one group (9 studies), unpublished studies including 6 datasets from the three studies of the present investigation, considering obese and control subjects separately; and published studies with two groups of subjects (three studies).

When analyzing data from one-population studies (Table 4), a subgroup of four studies was generated considering only reports including participants with BMI values below $27 \mathrm{~kg} / \mathrm{m}^{2}$. For this group, the pooled difference in BMI values was statistically significant $\left(+0.41 \mathrm{~kg} / \mathrm{m}^{2} ;[95 \% \mathrm{CI}\right.$ : +0.17 to +0.66$])$ for 3635 homo-/heterozygous carriers of the 363 allele compared to non-carriers.

We also examined the pooled difference in BMI between homo-/heterozygous carriers and non-carriers of the $363 \mathrm{~S}$ allele of the GRL gene in published articles with two population groups: a group of controls (normal weight subjects) and a group of cases (obese subjects). The pooled difference in BMI between homo-/heterozygous carriers and non-carriers of the 363 allele was not statistically significant when studies with normal weight subjects $(+0.56$ $\mathrm{kg} / \mathrm{m}^{2}$; [95\% CI: -0.072 to +1.19$\left.]\right)$ and obese subjects $\left(+0.32 \mathrm{~kg} / \mathrm{m}^{2}\right.$ [95\% CI: -0.82 to +1.46$\left.]\right)$ were considered separately. However, the pooled difference in BMI was negative and statistically significant in homo-/heterozygous carriers of the S363 allele when only novel data for normal weight subjects were examined $\left(-0.50 \mathrm{~kg} / \mathrm{m}^{2}\right.$; [95\% CI: -0.84 to -0.17$])$. Opposite tendencies for differences in BMI were also found when performing the metaanalysis after stratifying by gender, prevalence of the pol- 
Table 4: Pooled differences $(95 \% \mathrm{Cl})$ in body mass index $\left(\mathrm{kg} / \mathrm{m}^{2}\right)$ between individuals homozygous and heterozygous carriers of the 3635 allele of the GRL gene and homozygotes for the N363 allele. Fixed effects model

\begin{tabular}{|c|c|c|c|c|c|}
\hline Studies & $\begin{array}{c}\text { Difference in BMI }\left(\mathrm{kg} / \mathrm{m}^{2}\right) \\
\text { Pooled estimates }\end{array}$ & $95 \% \mathrm{Cl}$ & Q statistic & $\mathbf{k}$ & $\mathbf{p}^{\#}$ \\
\hline Overall studies & +0.18 & +0.004 to $+0.35^{*}$ & 84.47 & 21 & $<0.0001$ \\
\hline $\mathrm{BMI}<27 \mathrm{~kg} / \mathrm{m}^{2}$ & +0.14 & -0.052 to +0.32 & 29.15 & 10 & 0.0006 \\
\hline $\mathrm{BMI}>27 \mathrm{~kg} / \mathrm{m}^{2}$ & +0.37 & -0.047 to +0.79 & 54.31 & 11 & $<0.0001$ \\
\hline Adults (>25 years) & +0.51 & +0.31 to $+0.72 *$ & 27.47 & 16 & 0.0252 \\
\hline Children and adolescents ( $<25$ years) & -0.67 & -0.99 to $-0.35^{*}$ & 19.94 & 5 & 0.0005 \\
\hline \multicolumn{6}{|l|}{ - Ethnicity } \\
\hline European Countries & +0.16 & -0.01 to +0.34 & 74.84 & 15 & $<0.0001$ \\
\hline Australia & +0.45 & -0.34 to +1.24 & 9.03 & 5 & 0.06 \\
\hline \multicolumn{6}{|l|}{ - Gender } \\
\hline Men & -0.37 & -1.25 to $+0.5 \mathrm{I}$ & 1.20 & 3 & 0.5487 \\
\hline Men and women & +0.20 & +0.02 to +0.37 & 81.76 & 18 & $<0.0001$ \\
\hline \multicolumn{6}{|l|}{ - Mutation prevalence } \\
\hline$(<5 \%)$ & -0.54 & -0.96 to -0.12 & 20.69 & 6 & 0.0009 \\
\hline$(5-10 \%)$ & +0.34 & +0.15 to +0.54 & 37.74 & 9 & $<0.0001$ \\
\hline$(>10 \%)$ & +0.10 & -0.57 to +0.77 & 11.84 & 6 & 0.037 \\
\hline \multicolumn{6}{|l|}{ One population } \\
\hline $\mathrm{BMI}<27 \mathrm{~kg} / \mathrm{m}^{2}$ & +0.41 & +0.17 to $+0.66^{*}$ & 5.88 & 4 & 0.1177 \\
\hline $\mathrm{BMI} \geq 27 \mathrm{~kg} / \mathrm{m}^{2}$ & +1.19 & +0.64 to $+1.74^{*}$ & 13.34 & 5 & 0.0097 \\
\hline \multicolumn{6}{|l|}{ Normal weight subjects } \\
\hline already published data & +0.56 & -0.07 to +1.19 & 1.04 & 3 & $0.594 I$ \\
\hline novel data & -0.50 & -0.84 to $-0.17^{*}$ & 1.72 & 3 & 0.4227 \\
\hline \multicolumn{6}{|l|}{ Obese subjects } \\
\hline already published data & +0.32 & -0.82 to +1.46 & 0.07 & 3 & 0.9633 \\
\hline novel data & -1.26 & -2.10 to $-0.49 *$ & 15.77 & 3 & $<0.001$ \\
\hline
\end{tabular}

k: number of studies;

\# test for heterogeneity;

$* \mathrm{p}<0.05$ for the pooled difference in BMI.

ymorphism and considering children and adult populations, separately (Table 4).

We then estimated pooled odds ratios (ORs) and their 95\% confidence intervals (CIs) to further explore the association between the N363S polymorphism of the GRL gene and the likelihood of being obese (Figures 1, 2, 3). The relative risk of obesity linked to the N363S polymorphism was not significant (pooled OR $=1.71$; [95\% CI: $0.88-3.33]$ ), when data from previously published reports were used. If only the new data obtained from the present investigation were included, the OR for obesity of homo-/heterozygous carriers of the 363 S allele was statistically significant, but in the opposite direction (pooled $\mathrm{OR}=0.45$; [95\% CI: 0.24-0.85]). When these new data were pooled with previous findings in the meta-analysis, the overall risk of obesity linked to the polymorphism N363S was not statistically significant, revealing a pooled OR of 1.02 [95\% CI: 0.56-1.87].

\section{Discussion}

The present study was aimed to assess the effect of the N363S polymorphism of the GRL gene on the incidence of obesity. Although procedures of meta-analyses have mostly been applied to comprehensively examine the results from previously reported studies, we here also include novel data from three studies derived from Spanish and German populations of our group that have not been published so far. Moreover, the meta-analysis was performed only after relevant data that were not available in the original publications were obtained contacting directly with the authors. The new data set was generated using two different strategies: the first was to match controls to cases by gender and age, whereas the second one was performed as a case-parent study that can be considered as a special type of case-control study in which cases (unrelated probands) and pseudocontrols (parental nontransmitted alleles) are matched by ethnic origin. The magnitude of the association can be assessed by odds ratios (OR) in the case-control study, while the deviations of the transmission probabilities from the expected value under the null hypothesis of no-association $(50 \%)$ are related to the genotype relative risk [32]. The close proximity of point estimates for ORs (Figure 3 ) with values below 1.0 and the transmission probabilities found in the case-parent study do not suggest a positive association between the N363S polymorphism of the GRL gene and childhood obesity in the German population. 


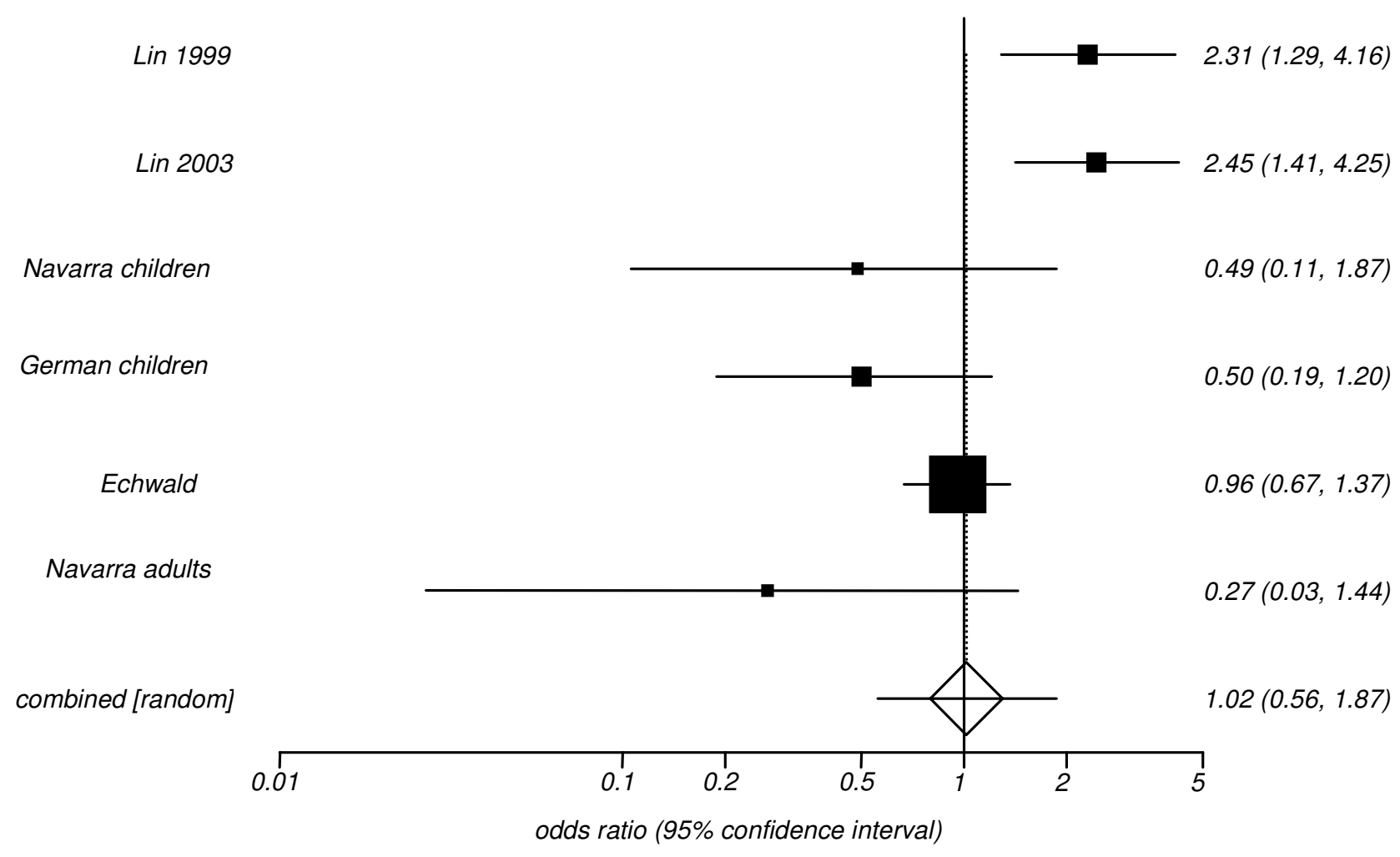

\section{Figure I}

Odds Ratios with the $95 \% \mathrm{Cl}$ for the association between presence of the N363S polymorphism of the GRL gene and the likelihood of being obese in the overall studies. In the study by Echwald et al (200I) only men were recruited from Copenhagen, Denmark, mean age $=45$. The study by Lin et al $(1999)$ included men $(53 \%)$ and women $(47 \%)$, mean age $=50$, from Sydney (Australia), the study by Lin et al $(2003)$ included men $(80 \%)$ and women $(20 \%)$, mean age $=45$, from Sydney (Australia). The Navarra adults study enrolled men $(20 \%)$ and women $(80 \%)$, mean age $=40$, from Navarra (North of Spain). The Navarra children study encompassed boys (53\%) and girls $(53 \%)$, mean age = II from Navarra (North of Spain). The German children study consisted of boys (50\%) and girls (50\%), mean age $=14$ from West and South Germany. Test for heterogeneity $Q=24.2 ; 5 \mathrm{df} ; \mathrm{p}<0.0 \mathrm{I}$.

We further addressed the general prevalence of the N363S polymorphism of the GRL gene and found it to be slightly more frequent in the German than in the Spanish study groups. Across populations, the genotype frequency of the polymorphism of the GRL gene varies widely. In Europe, it ranges from $4 \%$ to $6 \%$ for homo-/heterozygous carriers of the 363S allele in German, Spanish, French or British subjects and between 9\% and 15\% in Swedish and Danish individuals $[6,10,11,14,17]$ Australian populations have higher frequencies of homo-/heterozygous carriers of the 363 -allele, ranging from $12-13 \%$ in normal weight individuals to $26-27 \%$ in obese subjects (Tables 2 and 3 ; $[12,15,16])$. There are also important differences in the genotype frequency of the polymorphism in obese and non-obese subjects in several other populations. Surprisingly, for the Spanish and German normal weight groups, the number of homo-/heterozygous carriers of the $363 \mathrm{~S}$ allele of the GRL gene was higher compared to that found in obese subjects of the same population groups (Table $3)$.

To confirm the strength of our findings and because inconsistent data have been reported on the relationship between the N363S polymorphism of the GRL gene and obesity phenotypes $[33,34]$, after adding our own new data to previously published results, data from 5,909 unrelated subjects from a diverse ethnic backgrounds were pooled together for the analysis of BMI differences between homo-/heterozygous carriers and non-carriers of the $363 \mathrm{~S}$ allele of the GRL gene. The overall pooled estimated genotype frequency for homo-/heterozygous carriers of the 363 S allele was $4.47 \%$ (95\% CI: 4.24-5.30) with a substantial heterogeneity $(\mathrm{p}<0.001)$. Interestingly, for BMI differences, the overall estimation was $+0.18 \mathrm{~kg} / \mathrm{m}^{2}$ (95\% CI: +0.004 to +0.35 ) higher in homo-/heterozygous carriers of 3635 allele of the GRL gene than in non-carri- 


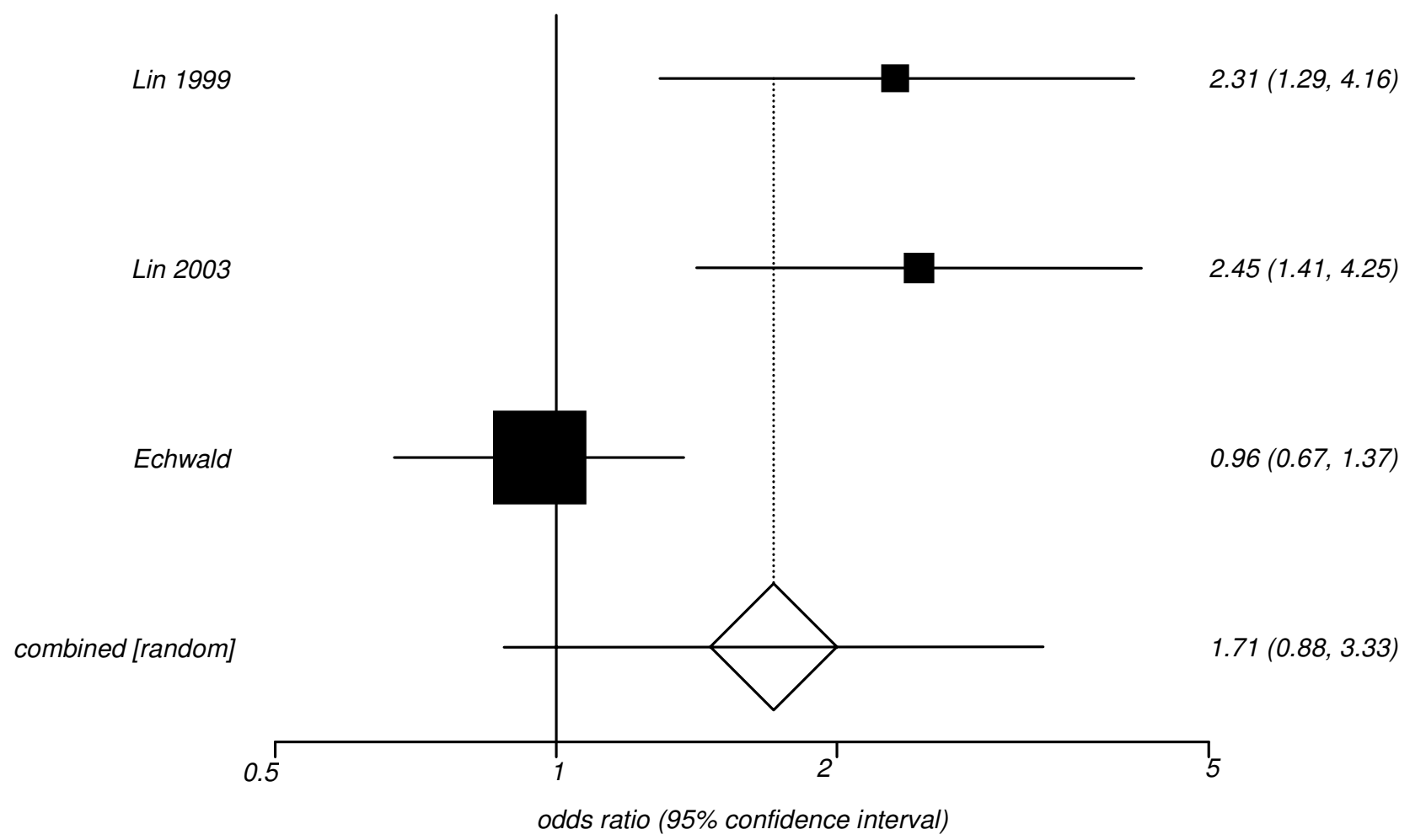

Figure 2

Odds Ratios with the $95 \% \mathrm{Cl}$ for the association between presence of the N363S polymorphism of the GRL gene and the likelihood of being obese in the published studies. In the study by Echwald et al (200I) only men, mean age $=45$, were recruited from Copenhagen, Denmark. The study by Lin et al (1999) included men (53\%) and women (47\%), mean age $=50$, from Sydney (Australia), the study by Lin et al $(2003)$ included men $(80 \%)$ and women $(20 \%)$, mean age $=45$, from Sydney (Australia). Test for heterogeneity $Q=12.3 ; 2 \mathrm{df} ; \mathrm{p}<0.0 \mathrm{I}$.

ers, also with an important heterogeneity $(\mathrm{p}<0.001)$. It is worthwhile to mention that the pooled analysis (i.e. the "one population studies") revealed a large range for BMI: from non-obese (mean BMI $=21.1 \mathrm{~kg} / \mathrm{m}^{2}$, ref. 14 ) to severely-obese individuals (mean BMI $=41.7 \mathrm{~kg} / \mathrm{m}^{2}$, ref 11 ) and also with regard to age: from 18 years [14] to 6668 years [7]. Moreover, three studies were only conducted with men $[9,10,14]$, while four studies included male and female subjects $[6,7,11,13]$. Disparities in BMI across studies as well as age and sex variability may at least partly account for the observed heterogeneity (Table 2).

Interestingly, when a subgroup of data was generated considering only reports whose participants showed a BMI below $27 \mathrm{~kg} / \mathrm{m}^{2}$, the pooled difference in BMI values for homo-/heterozygous carriers of the 363 S allele vs. noncarriers was statistically significant and homogeneous $\left(+0.41 \mathrm{~kg} / \mathrm{m}^{2} ; 95 \%\right.$ CI: +0.17 to +0.66$)$ with a $p$-value for heterogeneity of 0.12 . Funnel plots of effect estimates (differences in BMI) against sample size showed symmetrical distribution suggesting that there was no apparent publication bias in the available studies.

With regard to the meta-analysis, a drawback of the OR analysis is the use of different criteria to define obese and non-obese individuals in the various studies. Some examinations (e.g. Echwald et al. 2001, and Navarra studies) were based on rather low BMI thresholds for obesity, whereas others included morbidly-obese patients with BMI values well above $35 \mathrm{~kg} / \mathrm{m}^{2}[16]$. Moreover, there are important differences in age and sex among the groups analysed. Because the respective information was not provided in all studies, age and sex effects could not be adequately addressed in the current meta-analysis.

Two groups of children and adolescents (boys and girls) were included in the German and Spanish studies as well as one large group of young men with a mean age of about 27 years [17]. The other three studies were conducted in adults. In two studies $[15,16]$, the criteria for age and per- 


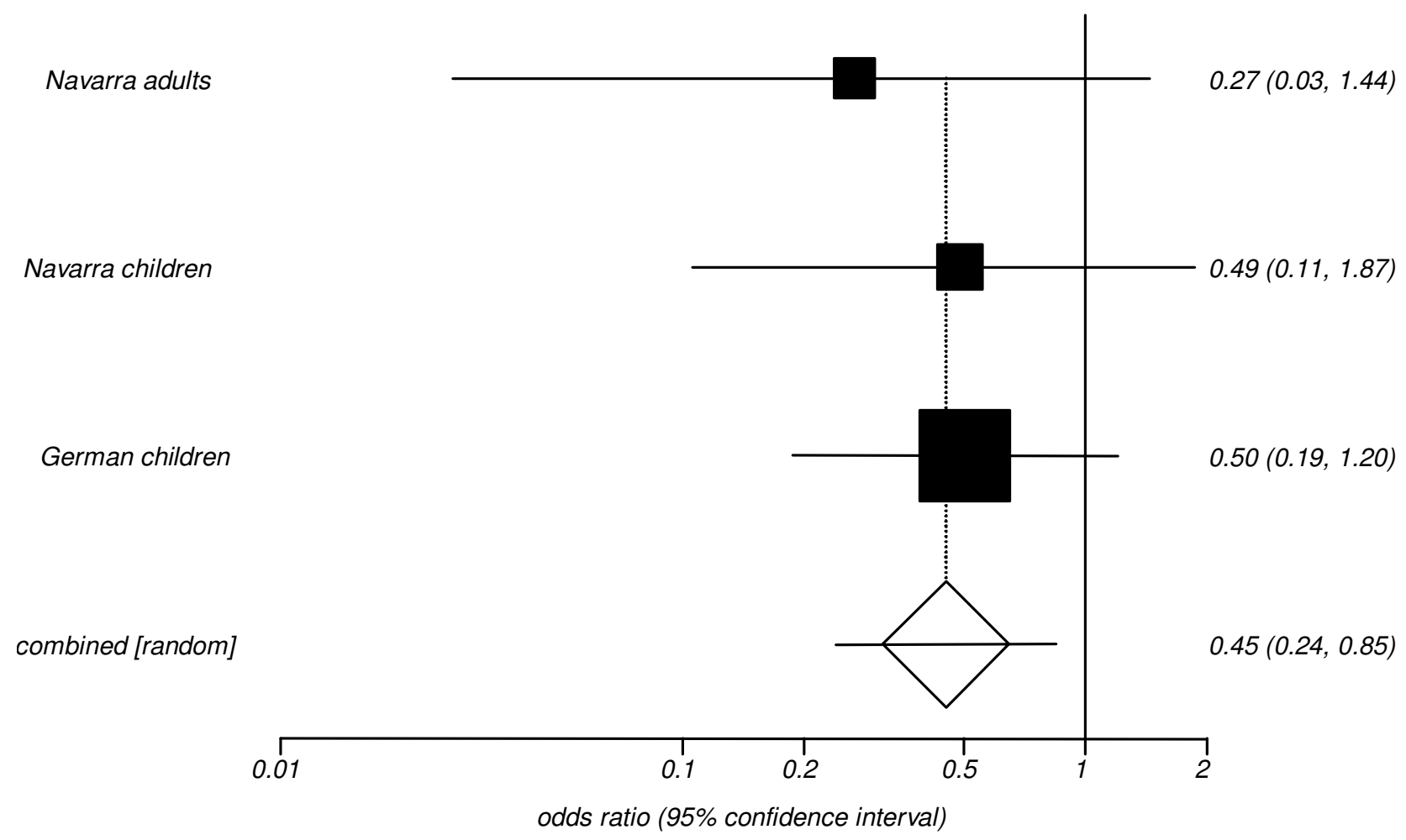

Figure 3

Odds Ratios with the $95 \% \mathrm{Cl}$ for the association between presence of the N363S polymorphism of the GRL gene and the likelihood of being obese in the unpublished studies. The Navarra adults study enrolled men $(20 \%)$ and women $(80 \%)$, mean age $=40$, from Navarra (North of Spain). The Navarra children study encompassed boys (53\%) and girls (53\%), mean age $=$ II from Navarra (North of Spain). The German children study consisted of boys $(50 \%)$ and girls $(50 \%)$, mean age $=14$ from West and South Germany. Test for heterogeneity $Q=0.49 ; 2 \mathrm{df} ; \mathrm{p}=0.78$.

centage of males were quite similar -an age range of 4852 years and a percentage of $49-57 \%$ of males- while in the third, the mean age of subjects was different (39-42 years old) as was the percentage of males (12-26\%, Table $1)$.

Overall, our analyses did not indicate an increased risk for the development of obesity for homo-/heterozygous carriers of the $\$ 363$ allele of the GLR as shown by a pooled OR of 1.02 (95\% CI: 0.56-1.87). Interestingly, an inverse association $(\mathrm{OR}=0.45)$ was obtained after pooling the German and Spanish studies for homo-/heterozygous carriers of the $363 \mathrm{~S}$ allele compared to non-carriers, suggesting population differences for this parameter. Beyond the already mentioned limitations of our meta-analysis, our study provides a sound base for the further investigation on the role of the polymorphism N363S of the GRL gene in large population samples of diverse ethnic origins [34]. It also yields a much better opportunity for the detection of significant effects in sub-group analyses of homogene- ous data. Thus, the meta-analysis represents a useful strategy to assess the potential contribution of variants with rather low allele frequencies (i.e. the N363S polymorphism of the GRL from 4 to $9 \%$ ), which may exert only moderate effects on polygenic disorders.

\section{Conclusion}

Although certain genotypic effects could be populationspecific, we conclude that there was no compelling evidence that the N363S polymorphism of the GRL gene is associated with the average BMI or with an increased prevalence of obesity, in the large number of human studies included in our analyses.

\section{Competing interests}

The author(s) declare that they have no competing interests. 


\section{Authors' contributions}

AM participated in the design of this study, recruited the meta-analysis data, contributed to the analysis and interpretation of the data, was responsible for Spanish subject enrolment and draft the manuscript. MCO carried out the laboratory analyses, participated in the analysis and interpretation of the data and helped to draft the manuscript. ASV made the statistical analysis and figures. JAM ad MAMG participated in the design of this study and in the analysis and interpretation of the data. $\mathrm{JH}, \mathrm{AH}$ and $\mathrm{HV}$ participated in the initiation and design of this study and in the analysis and interpretation of the data and were responsible for German subjects enrollment. All authors read and approved of the final manuscript.

\section{Acknowledgements}

The authors are grateful for the participation of subjects and their families, the contributions of the participants and authors of the studies from the literature used for the meta-analysis and the collaboration of GENOI members (Azcona C, Patiño A, Chueca M, Oyarzabal M, Pelach R, Berrade S, Gainza R, Moreno-Aliaga MJ) as well as Forga, $L$ and Corbalan MS. This work was supported by grants for the Navarra Government and Línea Especial (University of Navarra). We are grateful for the excellent technical assistance of Veronica Ciauriz, Gerti Gerber and Ana Lorente. The study was supported by grants of the BMBF (NGFNI and 2; 0IGSOII 8 and 0IGS0482).

\section{References}

I. Bell CG, Walley AJ, Froguel P: The genetics of human obesity. Nat Rev Genet 2005, 6:22I-234.

2. Perusse L, Rankinen T, Zuberi A, Chagnon YC, Weisnagel SJ, Argyropoulos G, Walts B, Snyder EE, Bouchard C: The human obesity gene map: the 2004 update. Obes Res 2005, 1 3:38I-490.

3. Marti A, Moreno-Aliaga MJ, Hebebrand J, Martinez JA: Genes, lifestyles and obesity. Int j Obes Relat Metab Disord 2004, 28 Suppl 3:S29-36.

4. Rosmond R: The glucocorticoid receptor gene and its association to metabolic syndrome. Obesity research 2002, I 0:1078-1086.

5. Van Rossum EF, Lamberts SW: Polymorphisms in the glucocorticoid receptor gene and their associations with metabolic parameters and body composition. Recent Prog Horm Res 2004, 59:333-357.

6. Roussel R, Reis AF, Dubois-Laforgue D, Bellanne-Chantelot C, Timsit J, Velho G: The N363S polymorphism in the glucocorticoid receptor gene is associated with overweight in subjects with type 2 diabetes mellitus. Clin Endocrinol (Oxf) 2003, 59:237-24I.

7. Huizenga N, Koper JW, de Lange P, Pola H, Stolk R, Burger H, Grobbee $\mathrm{DE}$, Brinkmann AO, de Jong FH, Lamberts S: A polymorphism in the glucocorticoid receptor gene may be associated with an increased sensitivity to glucocorticoids in vivo. The journal If clinical endocrinology and metabolism 1998, 83: I44-I5I.

8. Halsall D, Luan J, Hales N, Wareham NJ, O'Railly S: Rapid Response. Glucocorticoid receptor variant and body mass index. BM] [htpp://bmjcom/elettrers/3/9/722 ///337] 2000.

9. Rosmond $R$, Bouchard C, Bjorntorp $P:$ Tsp5091 polymorphism in exon 2 of the glucocorticoid receptor gene in relation to obesity and cortisol secretion: cohort study. BMJ 200I, 322:652-653.

10. Rosmond R: Letter: Glucocorticoid receptor $\mathbf{N} 3635$ variant in obesity: comes into vanity and goes into darkness. Obesity research 2003, II:1606-1607.

II. Dobson MG, Redfern CPF, Unwin N, Weaver JU: The N363S polymorphism of the glucocorticoid receptor: potential contribution to central obesity in men and lack of association with other risk factors for coronary heart disease and diabetes mellitus. Journal of clinical endocrinology and metabolism 2001, 86:2270-2274.

12. Morris BJ, Lin RC, Wang XL, Dalziel B, Caterson ID: Response: Central Obesity Is Associated with Glucocorticoid Receptor N363S Variant: Big Picture Sheds Light. Obesity Research 2003, I I:1607-1069.

13. Syed AA, Irving J, Redfern C, Hall AG, Unwin NC, White M, Bhopal RS, Alberti K, Weaver JU: Low prevalence of the N363S polymorphism of the glucocorticoid receptor in South Asians living in the United kingdom. The journal If clinical endocrinology and metabolism 2004, 89:232-235

14. Wust S, Van Rossum EF, Federenko IS, Koper JW, Kumsta R, Hellhammer $\mathrm{DH}$ : Common polymorphisms in the glucocorticoid receptor gene are associated with adrenocortical responses to psychosocial stress. J Clin Endocrinol Metab 2004, 89:565-573.

15. Lin RC, Wang WY, Morris BJ: High penetrance, overweight, and glucocorticoid receptor variant: case-control study. Bmj 1999, 31 9:1337-1338.

16. Lin RCY, Wang XL, Dalziel B, Caterson ID, Morris DJ: Association of obesity, but not diabetes or hypertension, with glucocorticoids receptor N363S variant. Obesity Research 2003, I I:802-808

17. Echwald SM, Sorensen TI, Andersen T, Pedersen O: The Asn363Ser variant of the glucocorticoid receptor gene is not associated with obesity or weight gain in Danish men. Int J Obes Relat Metab Disord 200I, 25: I563-1565.

18. Geller F, Reichwald K, Dempfle A, Illig T, Vollmert C, Herpertz S, Siffert W, Platzer M, Hess C, Gudermann T, Biebermann H, Wichmann HE, Schafer $H$, Hinney A, Hebebrand J: Melanocortin-4 receptor gene variant 1103 is negatively associated with obesity. Am J Hum Genet 2004, 74:572-58I.

19. Masud S, Ye S: Effect of the peroxisome proliferator activated receptor-gamma gene Prol2Ala variant on body mass index: a meta-analysis. J Med Genet 2003, 40:773-780.

20. Lohmueller KE, Pearce CL, Pike M, Lander ES, Hirschhorn JN: Metaanalysis of genetic association studies supports a contribution of common variants to susceptibility to common disease. Nat Genet 2003, 33:177-182.

2I. Heo M, Leibel RL, Fontaine KR, Boyer BB, Chung WK, Koulu M, Karvonen MK, Pesonen U, Rissanen A, Laakso M, Uusitupa MI, Chagnon Y, Bouchard C, Donohoue PA, Burns TL, Shuldiner AR, Silver K, Andersen RE, Pedersen O, Echwald S, Sorensen TI, Behn P, Permutt MA, Jacobs KB, Elston RC, Hoffman DJ, Gropp E, Allison DB: A meta-analytic investigation of linkage and association of common leptin receptor (LEPR) polymorphisms with body mass index and waist circumference. Int J Obes Relat Metab Disord 2002, 26:640-646

22. Ochoa MC, Marti A, Azcona C, Chueca M, Oyarzabal M, Pelach R, Patino A, Moreno-Aliaga MJ, Martinez-Gonzalez MA, Martinez JA: Gene-gene interaction between PPAR gamma 2 and ADR beta 3 increases obesity risk in children and adolescents. Int J Obes Relat Metab Disord 2004, 28 Suppl 3:S37-4I.

23. Corbalan MS, Marti A, Forga L, Martinez-Gonzalez MA, Martinez JA: The risk of obesity and the Trp64Arg polymorphism of the beta(3)-adrenergic receptor: effect modification by age. Ann Nutr Metab 2002, 46: I52-I 58.

24. Hebebrand J, Himmelmann GW, Heseker H, Schafer H, Remschmidt $\mathrm{H}$ : Use of percentiles for the body mass index in anorexia nervosa: diagnostic, epidemiological, and therapeutic considerations. Int J Eat Disord 1996, 19:359-369.

25. O'Connell JR, Weeks DE: PedCheck: a program for identification of genotype incompatibilities in linkage analysis. $\mathrm{Am} J$ Hum Genet 1998, 63:259-266.

26. Schaid DJ: Transmission disequilibrium, family controls, and great expectations. Am J Hum Genet 1998, 63:935-941.

27. Greenland S: Meta-analysis. In Modern Epidemiology Edited by: Greenland KJRS. Philadelphia, PA, Lippincott Raven; 1998: 643-673.

28. Dickersin K: Systematic reviews in epidemiology: why are we so far behind? Int J Epidemiol 2002, 31:6-12.

29. Hedges LV: Estimation of effect size from a series of independent experiments. Psychol Bull 1982, 92:490-499.

30. Takkouche B, Cadarso-Suarez C, Spiegelman D: Evaluation of old and new tests of heterogeneity in epidemiologic meta-analysis. Am J Epidemiol 1999, 150:206-215.

31. DerSimonian R, Laird N: Meta-analysis in clinical trials. Control Clin Trials 1986, 7:177-188. 
32. Schaid DJ: Likelihoods and TDT for the case-parents design. Genet Epidemiol 1999, 16:250-260.

33. Buemann B, Black E, Holst C, Toubro S, Echwald S, Pedersen O, Astrup A, Sorensen T: The N363S polymorphism of the glucocorticoid receptor and metabolic syndrome factors in men. Obes Res 2005, 13:862-867.

\section{Pre-publication history}

The pre-publication history for this paper can be accessed here:

http://www.biomedcentral.com/1471-2350/7/50/prepub

Publish with Bio Med Central and every scientist can read your work free of charge

"BioMed Central will be the most significant development for disseminating the results of biomedical research in our lifetime. " Sir Paul Nurse, Cancer Research UK

Your research papers will be:

- available free of charge to the entire biomedical community

- peer reviewed and published immediately upon acceptance

- cited in PubMed and archived on PubMed Central

- yours - you keep the copyright

Submit your manuscript here:

http://www.biomedcentral.com/info/publishing_adv.asp 